\title{
Peptide Bond Formation by Using p-Nitrophenyl Esters
}

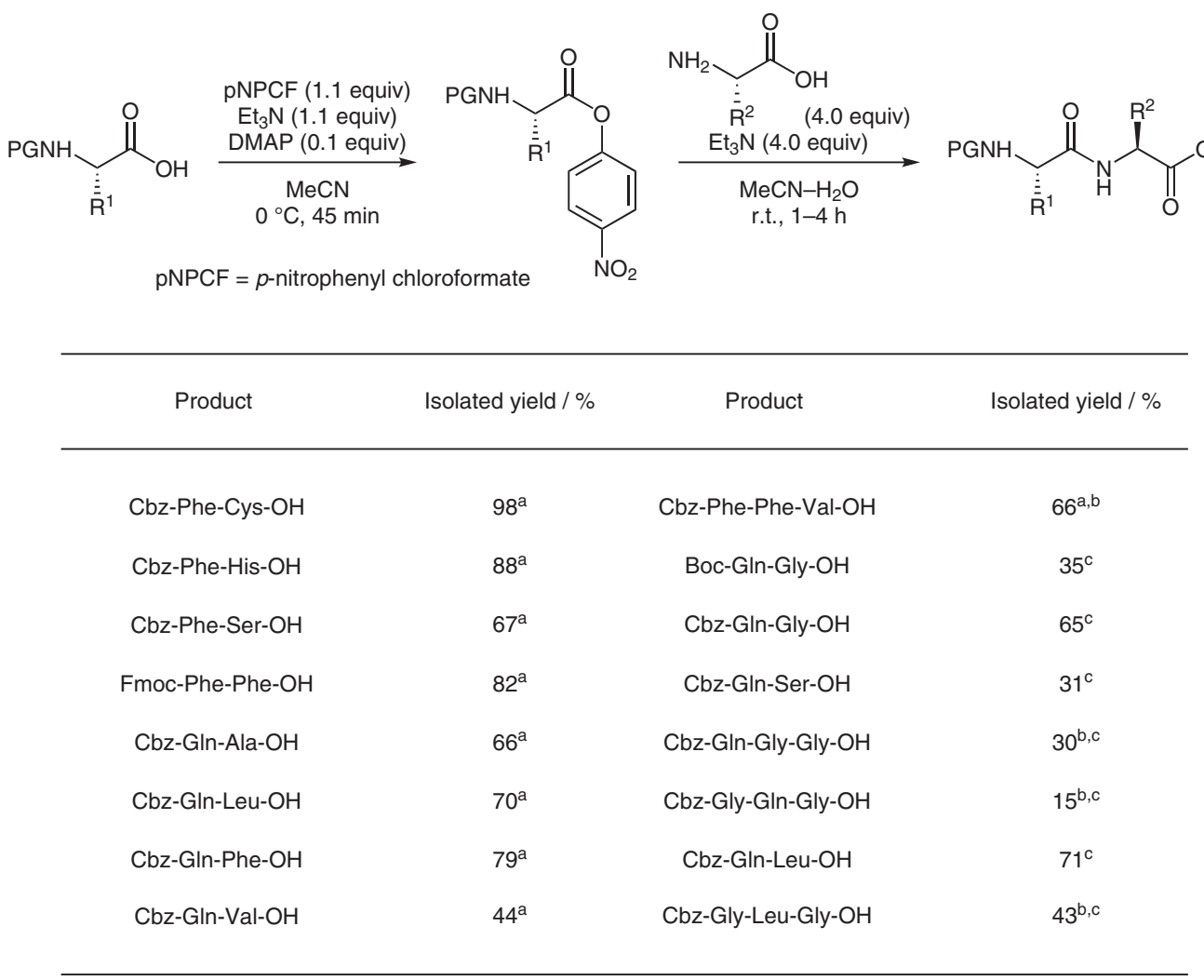

Peptide Chemistry

Key words

peptide bond formation

nitrophenyl esters

amino acids

${ }^{a}$ Purified by precipitation. ${ }^{b}$ Overall yield for two coupling steps. ${ }^{c}$ Purified by chromatography.

Significance: Reactive amino acid phenyl esters have been used in peptide synthesis. In 2002, Keillor and co-workers reported a method for peptide bond formation between $p$-nitrophenyl esters and unprotected amino acids in aqueous solution.
Comment: By using $p$-nitrophenyl esters formed in situ, various dipeptides or tripeptides were synthesized without classical peptide-coupling reagents. The yields of the target peptides were moderate to excellent. 